DOI: $10.14746 / \mathrm{amp} .2016 .21 .3$

\author{
STUART C. BATE \\ St Joseph's Theological Institute, Cedara \\ University of KwaZulu-Natal
}

\title{
Mission And Ministry In A Globalising World: An African Focus
}

\section{Introduction}

Globalisation refers to a process of increasing connectivity between previously small localised communities within a larger humanity. It happens mainly in the economic, social, political and cultural dimensions of human life.

Globalisation has been driven by a "technological revolution, centred on information technologies [which] began to reshape, at an accelerated pace, the material base of society" (Castells 2000, 1). This is turn has led to an ongoing transformation of human society linked to modernity in Western nations and its effects on the rest of the world, which has presently become a global village. Almost all countries and other political entities are experiencing "the increasingly interconnected character of the political, economic, and social life of the peoples on this planet" (Schreiter 1997, 5). This interconnectivity principally operates through the digital information revolution developing in our world based on three factors. The first was the development of computers which allowed people to generate information electronically. The second was the construction of the internet allowing information to be shared between computers almost instantly and globally. The third is the fact that the information revolution has led to the construction of a new and different form of social interaction in a new kind of social space, often referred to as cyberspace.

Electronic devices such as computers, mobile phones and television provide a means for human communication without their physical presence in the same geographical space. Consequently, new forms of social interaction have been created which never existed in the past. These new social spaces allow the construction of new cultural forms of communication and value construc- 
tion. The emergence of virtual social media platforms connecting people has become a major sign of our times. Facebook, Twitter, Snapchat, Xing, Renren and Linkedin are among the top ten online social networking groups. ${ }^{1}$ Consequently, the way human beings interact is being profoundly transformed. It is clear that such a new cultural domain, cyberspace, will lead to the emergence of new cultural forms and values. It is clearly inevitable that social identity and culture will follow, making an impact on human life within social spaces and culture within physical spaces. Such groups often connect people with similar interests and lifestyles. One consequence already visible is the construction of virtual social spaces populated by those having identities based on contentious areas of human identity, such as ethnic and racial prejudice, religious and ideological violence and sexual proclivity which then become culturally acceptable within the group. More positively, though, this technological revolution is bringing many positive benefits to many people. This is particularly the case in Africa where the impact has been correspondingly and comparatively greater than any where else in the world. This is because it has allowed communication to develop rapidly in spite of the very poor level of physical infrastructure such as railroads and electricity supply systems within the continent.

We can thus speak of this revolution leading to a new age or era based on a major human discovery. Such was the case following the human control of fire, writing, progress in natural science, and the emergence of the industrial revolution. I suggest that these events can often be correlated to the growth of empires in human history, a state which at the same time often brought both human progress for some and misery for others.

\section{The Link with Empires}

Globalisation and its impact on the world can in some ways be compared with the growth of empires in history. An empire is defined as a "supreme and extensive domination" (COED). Empires emerge as a result of specific tribes, nations or people who increasingly overcome other groups through war, economic or other powers and extend their rule over the defeated groups within the empire. The subjected peoples are gradually assimilated into the empire as their former leaders gradually conform to the values and beliefs and laws of the conquering group. Some authors have suggested that in globalisation, symbols of an empire and thus the religion of an empire are being constructed out of economic symbols (Nelson 2014).

${ }^{1} \mathrm{http} / /$ www.socialmediatoday.com/social-networks/2015-04-13/worlds-21-most-importantsocial-media-sites-and-apps-2015 . Accessed October 2016. 


\subsection{The Church and Empires}

The Church has had relationships with a number of empires in its history. In the time of the Roman Empire, it emerged as a small persecuted group only to grow until it came to exercise power within the empire through the communication of its message and its lifestyle. Gradually, the Church became an empire itself in the period after the edict of Milan and then in the Middle Ages, beginning with Charlemagne within the Holy Roman Empire. In the early Middle Ages, the church engaged with the growing empire of Islam. In the modern period, the church was associated with the European Colonial empires. In examining how the church responds to empires, we might look into our history, but generally it was a response to the challenges of the times (Bate 2013).

\section{Globalisation: its Consequences and Challenges}

Globalisation is developing most rapidly within the world of business, finance and trade. It can be expressed as growing interconnectivity of human groupings particularly on the level of business generation. Globalisation is fuelled by two main drivers. The first is the power of capitalisation through employment of resources to generate profit. The second is the growth of information technology in computers and international connectivity through the internet and social media to develop a globalised digital network. This results in an increase in the speed of the growth of the global empire at an astonishing rate in human history.

Productivity and competitiveness are, by and large, a function of knowledge generation and information processing; firms and territories are organized in networks of production, management and distribution; the core economic activities are global - that is, they have the capacity to work as a unit in real time, or chosen time, on a planetary scale (Castells 2001, 52).

\subsection{Socio-Cultural Trends and Consequences}

Globalisation leads to a number of socio-cultural trends which have been identified (Bate 2013, 321-322):

- Religion moves to the private sector (secularism).

- Increasing anomie regarding traditional forms of religion which do not seem to respond to the religious needs of people today.

- a growing preponderance of materialistic matters coupled with a decline in ethical behaviour and altruistic concern for the marginalised in society. 
- a growth in religious fundamentalism usually constructed around resistance identities which in the extreme may also manifest violent responses within society.

- the growth of consumer religion such as healing churches which market experiences of wellbeing and excitement to people with the request for money in donations, gifts, tithes or other forms of financial contribution for the services rendered. This is a consumer approach to religion based on personal needs.

Linked to these are identity issues. Globalisation affects the construction of human identity especially regarding beliefs and values. Castells $(1997,12)$ has identified four main areas in which identity is being reconstructed in globalising societies today. These are ethnic identity, religious fundamentalism, territorial identity and nationalism. Among the marginalised in society, the identities constructed can take the form of identities of resistance. Groups in society who reject globalisation do so because it has a negative impact on their lives. For example, some cities have fallen into decline and do not offer the quality of life they once did (Sugrue 2014).

Whether due to a loss of jobs, increasing poverty or the destruction of traditional forms of social infrastructure, resistance identities infer a strategy of rejection of the new system and a return to a more simple and often idealized past. Pasted onto this is a grudging use of the new system when it can further the goals of reconstruction of the new resistance identity. The growth of religious fundamentalism is one such area and linked to it is the growth of cults and the use of violence in such movements to achieve their goals. Al Qaeda and Daisha or the Islamic state are current examples of this. Outside of Islam, Christian identities using violence include American Militia movements (Mulloy 2004).

\subsection{Socio-Economic Trends and Consequences}

Globalisation also leads to a number of socio-economic consequences which have been identified (Bate 2013, 322). Social power in the world is undergoing a massive change in its distribution as some groups are amassing increasing power while others are being increasingly disempowered. Social wealth is one of the clearest examples of this. The information revolution has led to a massive increase in the wealth of the few at the top coupled with increasing poverty among the already poor, and the gap between the rich and poor continues to grow. Pope Francis' first message at the World economic forum in Davos stressed the dreadful consequences of this state of 
affairs. ${ }^{2}$ An example is the enormous, unjust debt burden that Africa carries. "The 48 countries of sub-Saharan Africa spend approximately $\$ 13.5$ billion every year repaying debts to rich foreign creditors for past loans" (UN 2003). This debt has been called "a new form of slavery, as vicious as the slave trade" by the All-African Conference of Churches (Walker). Another consequence is the massive growth of migration from the increasingly dispossessed parts of the world in the Middle East and Africa to the wealthier areas, especially Europe. This is often exacerbated by wars and conflicts in the dispossessed areas linked to conflicts with Islamic fundamentalism and resistance identities against American imperialism in the Gulf, North and East Africa and Afghanistan, such as in the early $21^{\text {st }}$ century.

\subsection{Socio-Psychological Trends and Consequences}

Globalisation also has psycho-somatic and psycho-sociological consequences in human life. Social circumstances such as those describe above always have an impact on psychological and physical well-being. The growth of the networked world creates both wellbeing and sickness in the lives of people. When societies function properly, they strive to meet the human needs of the population, and people feel well. Yet, when societies are disempowered, they become stressed, leading to compromised social circumstances for people. Poor social circumstances themselves can result in people experiencing the opposite of wellness, which I will call illness. Such societies can promote illness in the population in three different ways. The first is social deprivation, where being poor and deprived can clearly cause illness in itself. The second is the context of social deviation. Those who society considers to be deviants to the norm for whatever reason are likely to be negatively affected, and one of the consequences can be illness. Many of the recent Middle Eastern wars in Syria, Iraq and Yemen provide examples of this. A third social etiology of illness is living in a disorganized or dysfunctional society. Many modern migrants are moving because of this reality in the countries of their birth. The daily struggle of life in such a society becomes stressful, often promoting a state of unwellness, whether physically or psychologically, and this is known to result in illness. Psycho-social unwellness of this type always leads to a search for healing in order to get well. New religious and cultural healing therapies and structures in globalizing societies respond to this need.

${ }^{2}$ https://w2.vatican.va/content/francesco/en/messages/pont-messages/2014/documents/papafrancesco_20140117_messaggio-wef-davos.html 


\section{Globalisation and the Church: Constructing a Missionary Response}

Since the Second World War, Africa has changed from being a number of colonies of Europe and Neo-colonies of the cold war between the USA and the USSR to becoming an African Union of independent states undergoing rapid globalisation and economic development clustering with other developing countries in collaborative groupings of developing countries such as the BRICS group. ${ }^{3}$

The Church in Africa is the fastest growing church on a global scale, and Africa has been called "Christ's new homeland" (Sarah, Arinze et al 2015.) It is also a growing source of missionaries, especially to the West (Kwiyani 2014).

In proposing a missionary response to the consequences of globalisation, I want to make two proposals. The first involves the building of transformation identities based on the Paschal mystery in response to the partial and unsustainable responses found in secularism and naturalism which largely underpin the technical and social foundation of a globalised society. ${ }^{4}$ They are also responses to the resistance identities emerging among the marginalised in a globalising world. It is within this context that the psycho-social, socio-economic, and psycho-somatic trends and consequences emerge. This implies a missionary response to globalisation, secularism and scientism and the dangers of resistance based religion. ${ }^{5}$ Such a response requires the recovery and promotion of transcendence and the recovery of ritual and spirituality as vehicles for the evangelisation of secular society empowering the ministries of popular piety, retreat centres, sanctuaries and centres of prayer and reflection to provide an encounter with the transcendent God in a secular world. These are important themes in Evangelii Gaudium.

My second proposal is to focus on the missionary mandate of Matthew 10 as a biblical paradigm for Mission in a Global Village. The text was relatively less important for missionary activity in the modern period, often because of its focus on supernatural responses to demons and the raising up of the dead both of which were taken less seriously in the evolving scientific and humanistic paradigm of the modern period. Today, these ministries are increasingly important in the Church as new contextual and inculturated theologies reinterpret them by using traditional and postmodern cultural analyses.

The paradigm of the Matthew 10 text can be described in terms of seven central parameters: the notion of authority; the injunction to go to the lost

${ }^{3}$ BRICS Brazil, Russia, India, China and South Africa.

${ }^{4}$ For more on this see Bate 2016.

${ }^{5}$ We have to be careful here. Theologies of resistance can be transformative when they are based on a struggle against evil. Such was the case of some liberation theologies in Latin America, Black theologies in South Africa and the theology of Solidarność in Poland. 
sheep; the mandate to preach the kingdom of heaven; healing the sick; raising the dead and casting out demons. These are transcendent themes as a response to secular and naturalist challenges.

Matthew 28 and Matthew 10 both speak of the authority (exousia) given to Jesus from God as the source of his mission. Only after the resurrection is "all authority in heaven and earth given to the risen Christ (Mt 28:18). He then mandates the disciples to accomplish their mission but cautions them to wait for its empowering manifestation on the day of Pentecost from on high. This is when they receive the spiritual power required to animate authority in the gift of the Holy Spirit. Only then do they exit the upper room and begin to evangelise the lost sheep of the house of Israel.

In Matthew 10, the nature of the mission is specifically defined. It is a mission to "the lost sheep of the house of Israel" (verse 1). Authority given to the apostles is particularised rather than general. The authority over unclean spirits is to cast them out (v.1); it is to heal sickness and infirmity (v.1), to raise the dead and to preach that the Kingdom of heaven it as hand (v.7). The ministry of the apostles involves authority given to them by Jesus in order to carry out very specific tasks which appear to be very difficult things to do for an ordinary believer. In being sent to proclaim the kingdom of heaven, heal the sick, raise the dead, cleanse lepers and cast out demons, they are instructed to combat the influence of evil in the world they know and belong to.

Authority also has another dimension to it. This is the fact that those who are under authority accept the power over them. In particular, this includes the demons who recognise God's authority over them. It is the same with the authority of Jesus as the Gospels show us, especially in Matthew chapter 9, which relates to the healing of Jesus and his power over demons. It is this authority which is conferred to his apostles sent out in Chapter 10. The demons accept that Jesus has authority over them. When he approaches, they react strongly in fear of him (Mt 8,29-31; Lk 8,28-31) and when he casts them out he often does so by name (Lk 8:30; Mk 9,25). They reveal their name and the way in which they can be cast out (Sullivan 1987, 230). An example of this is the reaction of the world's economic powers at their annual meeting in Davos in 2014 to the message of Pope Francis delivered on the first day about the dangerous widening division between the rich and poor in a globalising world.

The Gospels first present the authority of Jesus in the story of his temptation by the Devil in the desert before he begins his ministry (Lk 4). Satan tempts Jesus by worldly power and wealth indicating the nature of evil and its ability to corrupt. Jesus recognises this foundational source of evil and responds to the devil citing God's authority over all these evils in human life. Authority for the person of faith always comprises this conflict and the ability to choose God's way over Satan's. All people of faith experience the struggle with evil 
and temptations in their lives. Only through this, and our choice of life in God, do we receive the ability to minister to others in God's authority. Jesus does not pass authority onto the disciples at the beginning, but only when they have been with him for some time. Participating in his ministry, they gradually become ready and gain experience in order to being their own mission and ministry. This is the process we call formation that all ministers have to experience before they are ready. Today, it must occur within the context of the reality of the powerful globalised world. It calls for a change of attitude for some leaders in the church and its mission. This is the change, to become mission focused, what Pope Francis calls the "self-referential" power of the Church to partake in mission based on the Joy of the Gospel as something to be experienced, witnessed and shared. ${ }^{6}$ It is for all people, but in a particular way, the focus is on the peripheries understood as contexts where the light of the sun has been lost or faded. The response here is referred to as the "new evangelisation“ or „re-evangelisation“ of fallen-away or lukewarm Christians or those who do not know Jesus or even reject him (EG §14-15, Cf. RM §33).

The greatest sign of Jesus' authority is his being present on the cross. It is here that in accepting the sins and evil of the world onto himself, he becomes a sacrificial victim for them. This appears to be the moment of defeat. Yet, in his words "it is accomplished" and „Father forgive them," the apparent defeat is transformed by the authority of the Father: he is raised from the dead after three days.

In John's Gospel, which reflects Jesus' authority more powerfully, this is manifest right through the trial, the journey to the cross and his death, when Jesus is exalted and draws all to himself. Those who wish to receive this ministry from Jesus should know that they will have little authority over the demons of the world if we have not waged battle with those present in our hearts, our families and in our own communities. This is the way in which we build up our knowledge and experience in the battle against evil, and in this way receive authority to cast out other demons in our ministry.

Matthew clarifies some specifics about this mission. First of all, it is a mission "to the lost sheep of the house of Israel" (Matt 10:7). It is a mission to the community, culture and society which Jesus and the disciples belong to, a missio ad intra. This contrasts strongly with the mission mandate of Mat-

${ }^{6}$ During the General Congregations prior to the Conclave, Cardinal Jorge Mario Bergoglio penned the following: "When the Church does not go out of herself to evangelize, she becomes selfreferential; she grows ill (like the stooped woman in the Gospel). The evils which appear throughout history in Church institutions are rooted in this self-referentiality, a kind of theological narcissism." Berg, T. 2013. Evangelii Gaudium: exhorting a self-referential Church. Catholic News Agency online, December 5, 2013. Viewed March 2015, <http://www.catholicnewsagency.com/column. php? $=2753>$. 
thew 28 which is a mission to the whole world and in particular those peoples who have never been evangelised. The missio ad intra is a powerful metaphor for the globalised world of today, where increasingly all participate in it; we are all within.

Second, it defines the imminent arrival of God's Kingdom which is "at hand." God is upon us and we can experience his saving power immediately. This is something good for us, it attracts, causing us to turn away from our current life project and be attracted by something better: an experience of the presence of the Kingdom of heaven in the journey of life. It is only when this happens in our lives that the experience of metanoia occurs. This "turning around" is a motion towards the good of the kingdom at hand, a treasure for us, which attracts us to turn towards it. Only on a secondary, causal level is this a turning away from our previous lifestyle with its elements of sin and evil. It is the Good News that saves us. Clearly the task of the missionary is to create a context that allows the good news to be at hand so that conversion may occur in this globalised world. An interesting example of this in the academic world is found in the debate between Cardinal Ratzinger and Jürgen Habermas in January 2004. Habermas had previously conceded that values such as human dignity and morality of consciousness and democracy are the legacy of "the Judaic ethic of justice and the Christian ethic of love... up to this day there is no alternative to it" (Habermas 2002:150-151).

Third, this is a mission to heal the sick. Such a mission is only required when human societies and cultures become fundamentally sick (Bate 1995, 283). But what kind of healing was this? It is important to return to the original Greek text in the New Testament. Latin and Western Europe translations of the texts are somewhat compromised as the nuanced meaning of the Greek often describes two or more different concepts in Western languages. The word here is therapeuo from which we get our English word therapy. Beyer (129) has shown that therapeuo is used in the New Testament in the "sense of 'to heal' and always in such a way that the reference is not to medical treatment, which might fail, but to real healing." Another word used for healing in the NT is the word (sozo) which can also mean to save or rescue. Healing as sozo "always refers to the whole person and not to individual parts of the body" (Foerster 990). It is concerned with restoring the fullness of human life in those who have lost it.

Such a holistic understanding of sickness and health is one of the signs of the postmodern age. Here is a metaphor that speaks powerfully to the people of our times and context. An important aspect of modernity is a loss of the sense of values, meaning and hope (anomie), which are replaced by a restless search for satisfaction in consumerism and spectacle (see Kraft 89-91). This too is a sickness of the contemporary age in need of healing. It is also 
a response to resistance identities which take refuge from the world in healing cults and violent movements.

Fourth, the mission is to raise the dead. In its broadest sense, this is a mission to bring life to a human being who is oppressed, sick and possessed. Jesus comes that we may have life to the full (John 3:16). It is in this sense that the mission to raise the dead as a mission to heal should be understood. In modern western culture, this text was often interpreted clinically, but this is a cultural limitation since such a resurrection is only promised at the end of time. This was a difficult text to live in that culture due to the didactic nature of modern western culture. In the cultural fusion brought about by globalisation and postmodern theories, the mission to raise the dead has become a source of good news since the limitation of the modern understanding is clear. The sense of deadness spoken about here needs to be interpreted for our time and culture.

The globalising world is often a place in which the plethora of images around us dulls us to the human condition which becomes social noise to be ignored. Exposure to the global realities of drugs, violence, HIV and AIDS and other sicknesses with social aetiologies does not have an impact on us as it used to. Often, the sense of life once found in smaller traditional cultures in the family, tribe and village and local community is being increasingly replaced by spiritual paralysis to the noise of global ills which the technologically linked global vision brings us. An increasing prioritising of materialistic matters results in the deterioration of ethical behaviour and concern for the exploited. Other aspects of social ethics result in our becoming increasingly detached from what makes us human, since we are increasingly attached to the material and the technical. What makes matters worse is when traditional forms of religious expression are no longer effective, and so we have no recourse to a life-giving remedy. Therefore, we search for simplistic highs in the lust for money, drugs and other substitutes for our fulfilment as a growing weariness and ennui emerges concerning traditional forms of religion, which in turn no longer meet the religious needs of people today.

These are the human conditions that need therapy for the restoration of life. It is a life for which people are increasingly searching and a challenge based on missionary enthusiasm.

Finally, this is a mission to cast out demons. Demons can be understood as powers that people do not comprehend but fear because they oppress certain people. They are so strong that people often believe they are unable to overcome them. They are experienced by people today in many ways. One such demon is present where a certain group of people is oppressed by a more powerful group. This experience has occurred in slavery, colonialism and empire building as well as in communist empire building and ideological control. They 
occur in unjust working conditions, racism and ethnic and religious cleansing. Casting out demons in this sense is a struggle against evils such as these.

The Christian response against such demons have often been missions and ministries of social justice against unjust regimes and systems. Such demons inhabit a world of increasing priority given to materialist concerns to the detriment of ethical behaviour and concern for the exploited. They speak of the growing global gap between the rich and the middle class on the one hand and the poor on the other. The church has been involved in missions like this and I have described earlier how such difficult situations are emerging in the globalized world. The mission here begins with naming the evil (the demon) and then finding the means to respond and overcome it. The Christian participation in Solidarnosc in Poland and the struggle against apartheid in South Africa are two examples of this mission.

Demons may also be understood today as the compulsions, obsessions and powerful structures which sometimes obsess and control people. In addition, the enormous quantity if events about which people hear can lead to oppression by the sheer size of what is going on. We are increasingly overwhelmed by the size of the world and its events. In response, we search for quick and easy solutions in order to deal with things. But these are never permanent. The demon remains.

\section{Rereading the Gospel from the Perspective of Matthew 10}

The mission mandate in Matthew 28 is configured in the context of all power having been given to the resurrected Lord who sends out his disciples to the whole world. However, the mission mandate in Matthew 10 appears to be more modest. It is a mission to the people of Israel who have lost their way. The focus is on healing and the life of God for us. Rather than going with power to the whole world, they go as innocent sheep into a dangerous world of wolves. The world often victimises the sheep through hatred, fear and violence. They may suffer and face persecution for their mission. This mandate teaches that as missionaries, we too will sometimes be victims just as the apostles were. Yet the mission to proclaim and work for harmony and peace in the struggle for the peace and harmony of the Kingdom of God which is our expectation is not that everyone will be converted or healed. Jesus and his apostles lived in a world of evil and sin just as we as we do today. Jesus died and rose to manifest the power of God's kingdom. We follow the apostles as we participate in making his kingdom present in our time. Our expectation should be that we will also be victims of the sins of the world. 
Therefore, the mission statement in Matthew 10 does not seem as clear as the assurance of Matthew 28. The mission mandate in Matthew 10 provides a framework within which the Gospel can be read to reveal the good news for us. The first words of Jesus in Mark's Gospel provide the light: "The time is fulfilled and the kingdom of God is at hand; repent, and believe in the Gospel" (Mk 1:14). It is Jesus who makes the kingdom present. He reveals its nature through the parables and in his preaching. He makes it present through the healings and miracles, 41 of which are attested to by the evangelists (Kelsey 55-57).

This is very nice good news for people, and the crowds grow and follow him. However, there is a deeper side to the good news which Jesus begins to reveal after seeing that the disciples have understood the message and who he is (cf. Mk 8). From then on, he begins to proclaim the journey to Jerusalem, ending in his suffering and death on the cross. After he has spoken about this deeper part of the gospel, Peter rebukes him, and the one who Jesus has proclaimed to be the rock on whom the Church will be built (Mt 16) is referred to as Satan, for "you are not on the side of God but of men." The message from then on becomes an increasingly hard good news and the crowds desert Jesus until on the cross he is left alone, abandoned and denied even by his closest disciples. For Christians, this part is the centre of the Good News. This is the mystery that we acknowledge by faith that saves us. Salvation and healing is centred in the paschal mystery. "The crucified is the unhealed" (O'Collins 1977: 77-84).

In our ministry, we are called to walk the same journey. In doing so, we receive God's power and authority as we become missionaries. The mission mandate of Matthew 10 requires than we live both the tough good news of the second part of the gospel experienced on the journey to Jerusalem as well as the apparently happier good news of the healings that God grants. When failures are ignored and suffering is downplayed, an important element of the life of Jesus that we are called to follow is ignored. Mathew's Gospel calls us to walk these two roads of the Christian path. The life we bring in healings and fighting demons is rooted in the suffering on the cross. The required spirituality is clear. It is to follow Jesus along the journey of the Good News and healing as it leads us to the way of the cross. Today, this is an invitation to enter into the suffering and pain of our Global Jerusalem on our a journey home to the Father. As we go, we should preach by saying "the kingdom of heaven is at hand" and we should heal the sick, raise the dead, cleanse lepers and cast out demons. What we have received we have received without pay. So we should give without pay in a world sold to money. 


\section{ABSTRACT}

Africa is currently undergoing rapid globalisation in many areas. This growth is particularly strong through mobile internet connectivity which is having a considerable impact on economic growth. There were six African countries among the world's top ten fastest growing economies between 2001 and 2010 - Angola, Nigeria, Ethiopia, Chad, Mozambique and Rwanda (Economist).

This article examines the current concerns related to globalisation in Africa. It then moves on to identify specific areas and issues for mission and ministry linked to the phenomenon of globalisation in Africa and elsewhere. It proposes solutions for effective strategies for mission and ministry in this context.

Keywords: African Mission today; globalisation; information technology; post colonialism; New Evangelisation

Słowa kluczowe: współczesne misje w Afryce; globalizacja; informatyka; postkolonializm; nowa ewangelizacja

\section{BIBLIOGRAPHY}

Bate, Stuart C. 1995. Inculturation and Healing: Coping-Healing in South African Christianity. Pietermaritzburg: Cluster.

Bate, Stuart C. 2013. Between Empire and Anti-Empire: African Mission in the $21^{\text {st }}$ Century Missionalia. 41, 3: 307-344.

Bate, Stuart C. 2016. A Theology of Development Based on Transformational Authority. Journal of Theology for Southern Africa 154: 59-86.

Beyer, H.W. 1993. therapeuo. Theological Dictionary of the New Testament. ed. G. Kittel, G. Friedrich. Michigan: WM. B. Eerdmans Publishing Company. 10 vol.

Castells, Manuel. 1997. The Information Age: Economy, Society and Culture. Volume II: The Power of Identity. Oxford: Blackwell.

Castells, Manuel. 2000. The information age: economy, society and culture. Volume I: The rise of the network society. Oxford: Blackwell. $2^{\text {nd }}$ edition.

Castells, Manuel. 2001 "Information technology and global capitalism" in: W. Hutton and A. Giddens. (eds.) On The Edge. Living with global capitalism, London: Vintage.

COED 2001. Concise Oxford English Dictionary, $10^{\text {th }}$ edition. Oxford: Oxford Press.

Economist 2011. Africa's impressive growth.

$<$ http://www.economist.com/blogs/dailychart/2011/01/daily_chart> Accessed August 2011.

EG. Evangelii Gaudium. Apostolic Exhortation of Pope Francis. Vatican 2013. $<$ http://w2.vatican.va/content/francesco/en/apost_exhortations/documents/papa-francesco_ esortazione-ap_20131124_evangelii-gaudium.html >. Accessed March 2015.

Foerster, W. 1993. Sozo. Theological Dictionary of the New Testament. ed. G. Kittel, G. Friedrich. Michigan: WM. B. Eerdmans Publishing Company. 10 vol.

Gould, S. 1980. The Panda's Thumb: More Reflections on Natural History. NY: Norton.

Habermas, Jürgen. 2002. Religion and Rationality: Essays on Reason, God, and Modernity. Cambridge Ma: MIT Press.

Kelsey, M. 1973. Healing and Christianity. NY: Harper \& Row. 
Kwiyani, Harvey. 2014. Sent Forth: African Missionary work in the West. NY: Orbis.

Kraft, M.G. 1995. Understanding Spiritual Power. NY: Orbis.

Mulloy, D., 2004. American extremism: History, politics and the militia movement. Routledge.

Nelson, Robert. H. 2014. Economics as religion: From Samuelson to Chicago and beyond. Penn: State Press.

O’Collins, G., 1977. The Calvary Christ. Westminster: John Knox Press.

Redemptoris Missio on the Permanent Validity of the Church's Missionary Mandate. Encyclical Letter of Pope John Paul II December 7 1990. Viewed March 2015.

$<$ http://w2.vatican.va/content/john-paul-ii/en/encyclicals/documents/hf_jp-ii_enc_07121990_ redemptoris-missio.html > . Accessed March 2016.

Sara, Robert. Arinze, Francis. et al. 2015, Christ's New Homeland-Africa: Contribution to the Synod on the Family by African Pastors. San Francisco: Ignatius.

Schreiter, R. 1997. The New Catholicity. New York: Orbis.

Sullivan, L. 1987. Healing. In Eliade, M. ed. The Encyclopedia of Religion. NY: Macmillan. Vol 6:226-234

Sugrue, T.J., 2014. The origins of the urban crisis: Race and inequality in post-war Detroit. Princeton University Press.

UN 2003. United Nations Human Development Report. $<$ http://hdr.undp.org/en/content/human-development-report-2003>. Accessed April 2016.

Walker, Wyatt. 2000. Africa Enslaved by Debt. Metro exchange Dec 2000. $<$ http://kora.matrix.msu.edu/files/50/304/32-130-1F9E-84-GMH\%20ACOA\%20WT\%20Walker\%2012-2000\%20opt.pdf>. Accessed April 2016.

StUART C. BATE OMI DR., is the Research and Development Officer at St. Joseph's Theological Institute, Cedara South Africa and a staff member in the School of Religion, Philosophy and Classics at the University of KwaZulu-Natal, South Africa. He is a missiologist with a special interest in the mission to heal as well as religious and cultural healing in general. He has published two books and edited two others, as well as a number of articles in this area, including in the context of HIV and AIDS. These studies form part of his wider interest in the interface between the Church and globalisation in the context of the growth of information technology and the networked world. He has published both internationally and locally in this area. The focus on Mission in a globalising Africa here examines another aspect of this greater context. 


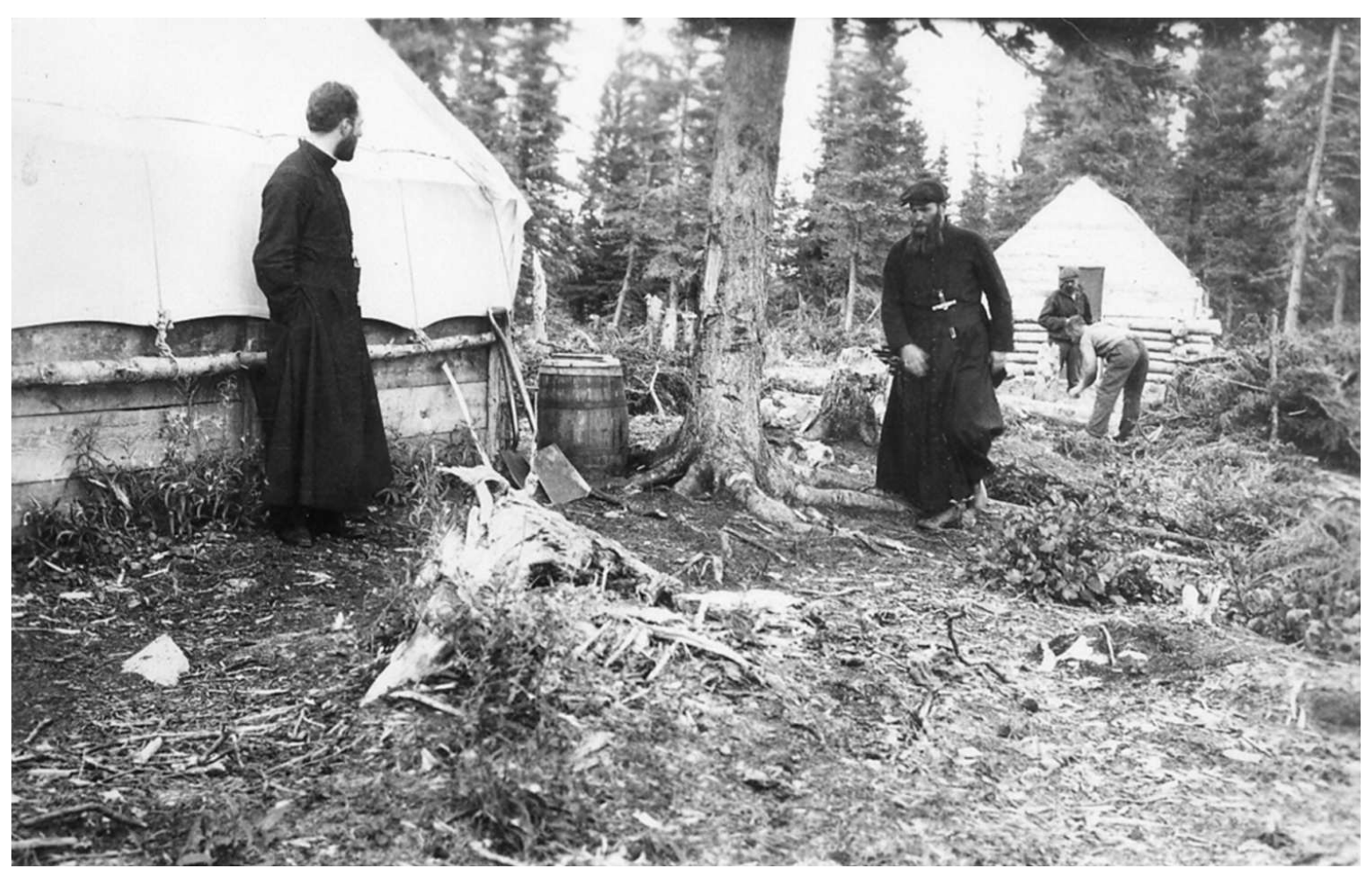

Vieux Comptoir - budowa misji, wrzesień 1937 


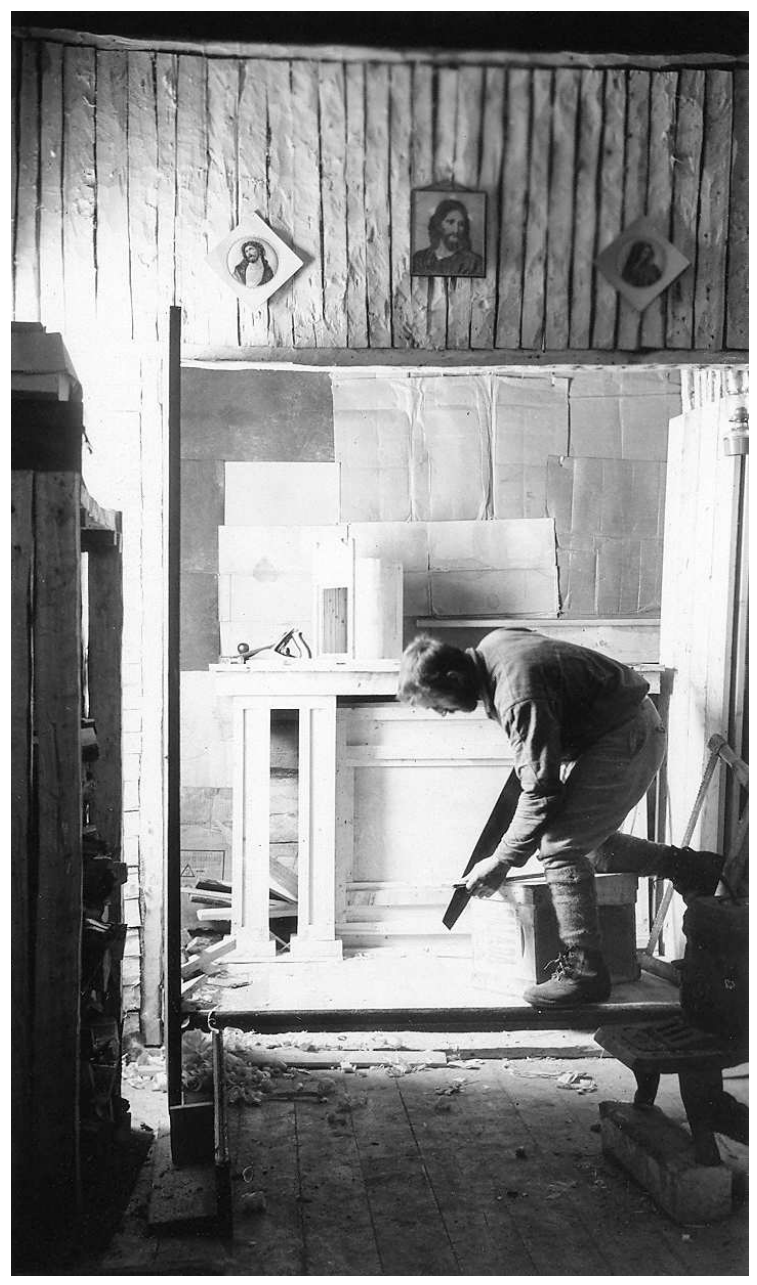

Vieux Comptoir - budowa misji, listopad 1937

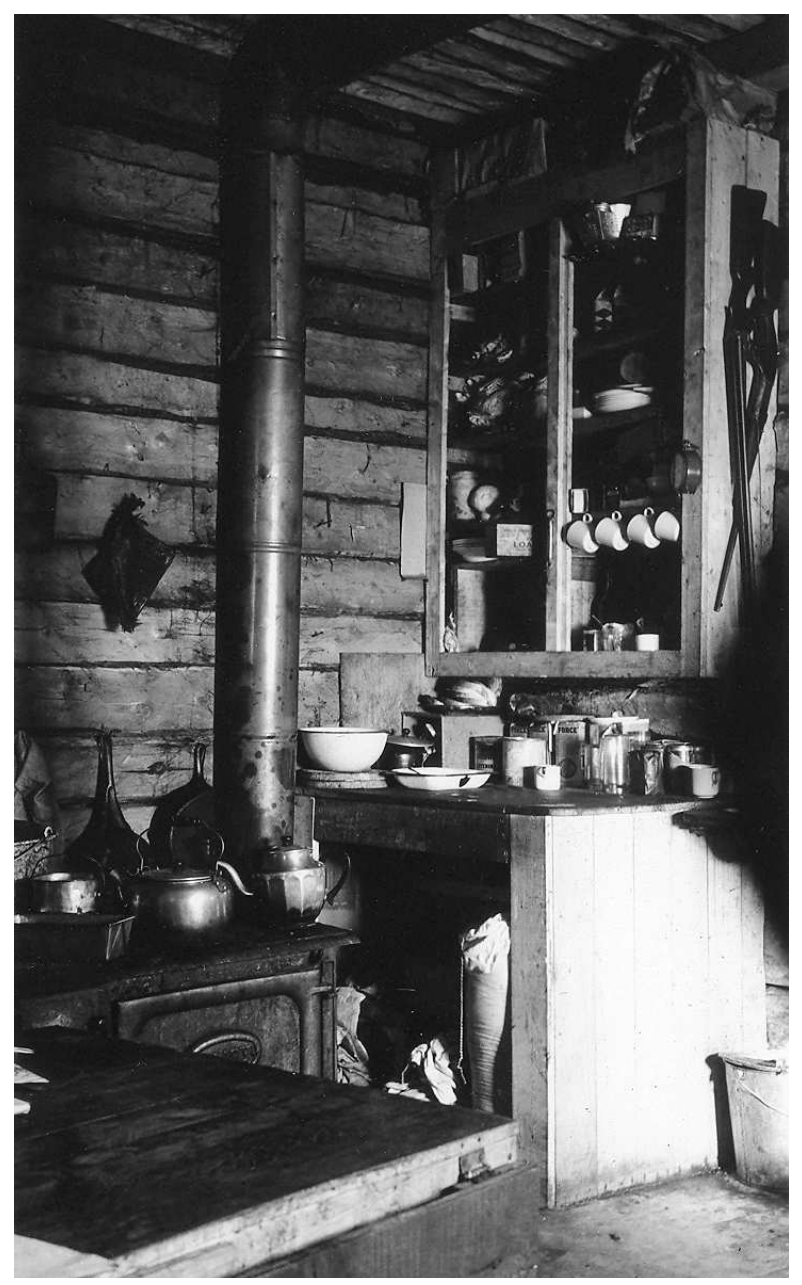

Vieux Comptoir - budowa misji, listopad 1937 